\title{
Effect of Hydrothermal Media on the in-situ Whisker Growth on Biphasic Calcium Phosphate Ceramics
}

This article was published in the following Dove Press journal:

International Journal of Nanomedicine

\section{Cong Feng \\ Yonghao $\mathrm{Wu}$ \\ Quanle Cao \\ Xiangfeng Li \\ Xiangdong Zhu (iD) \\ Xingdong Zhang}

National Engineering Research Center for Biomaterials, Sichuan University, Chengdu, Sichuan, People's Republic of China
Correspondence: Xiangfeng Li; Xiangdong Zhu

Sichuan University, No. 24 South Section I,

Yihuan Road, Chengdu 6I0065, People's

Republic of China

$\mathrm{Tel} / \mathrm{Fax}+86-2885417654$

Email hkdlxiangfeng@।63.com;

zhu_xd1973@scu.edu.cn
Background: There is still a big challenge to achieve a balance between mechanical characteristics and biological properties in biphasic calcium phosphate (BCP) ceramics.

Purpose: The present study focused on the in-situ whisker growth on BCP ceramics via different hydrothermal treatments and investigated the influences of these whiskers on the mechanical property and biological performance of the ceramics.

Methods: Five kinds of BCP ceramics with in-situ whisker growth, ie, BCP-C, BCP- $\mathrm{HNO}_{3}$, BCP-Citric, BCP-NaOH, BCP-CaCl 2 and $\mathrm{BCP}-\mathrm{Na}_{3} \mathrm{PO}_{4}$ were fabricated by different hydrothermal treatments. The phase compositions, morphologies, crystal structures and mechanical strengths of the obtained BCP ceramics were firstly characterized. Then, the in vitro cell adhesion, proliferation and alkaline phosphatase (ALP) activity of bone marrow stromal cells (BMSCs) on the BCP ceramics were evaluated. Lastly, the effects of in-situ whisker growth on the bone-like apatite formation abilities of BCP ceramics were also investigated by immersing them in simulated body fluid (SBF).

Results: The results demonstrated that the hydrothermal conditions, especially the hydrothermal media, were crucial to determine the phase composition and morphology of the insitu whisker. Especially among the five media used $\left(\mathrm{HNO}_{3}\right.$, Citric, $\mathrm{NaOH}, \mathrm{CaCl}_{2}$ and $\mathrm{Na}_{3}$ $\mathrm{PO}_{4}$ ), the $\mathrm{Na}_{3} \mathrm{PO}_{4}$ treatment resulted in the shortest whisker with a unique hollow structure, and kept the original biphasic composition. All five kinds of whiskers increased the mechanical strength of BCP ceramics to some extent, and showed the good ability of bone-like apatite formation. The in vitro cell study demonstrated that the in-situ whisker growth had no adverse but even positive effect on the adhesion, proliferation and ALP activity of BMSCs. Conclusion: Due to the growth of in-situ whiskers, the mechanical property and biological performance of the obtained BCP ceramics could increase simultaneously. Therefore, in-situ whiskers growth offers a promising strategy for the expanded application of $\mathrm{BCP}$ ceramics to meet the requirements of regenerative medicine.

Keywords: in-situ whisker, hydrothermal treatment, biphasic calcium phosphate, mechanical property, bioactivity

\section{Introduction}

Calcium phosphate (Ca-P) ceramic is known as an ideal material for bone repair due to its similarity to the composition of natural bone, bioactivity, degradability and osteoinductivity. ${ }^{1,2}$ Among them, biphasic calcium phosphate (BCP) ceramic has become a better choice, due to its suitable degradation and excellent osteoinductivity. ${ }^{3,4}$ However, the traditional BCP bioceramics are still far from satisfactory for the requirements of regenerative medicine, and need more optimizations to endow them with superior bioactivity and regenerative ability. From the point of view of regenerative medicine, a biomaterial could induce a damaged 
tissue to regenerate by the optimized design of material itself, rather than adding any living cell or growth factor. ${ }^{5}$ Moreover, another important aspect is that the brittleness and low mechanical property of $\mathrm{BCP}$ bioceramics restrict the usage to bone defect filling. ${ }^{6}$ Therefore, the development of porous BCP ceramics with superior bioactivity and enhanced mechanical property is of great importance.

Among a variety of material characteristics of BCP ceramics, the surface topographies play a quite important role in determining their biological performances, which directly affect the fate decision of stem cells. Recent studies have demonstrated that several specific micro-/nano- topographies, eg, nanotube, ${ }^{7}$ nanowires, ${ }^{8}$ pillars ${ }^{9}$ and pits $^{10}$ could induce the osteogenic differentiation of stem cells and further promote the regeneration of damaged tissues. The excellent work by M.J. Dalby ${ }^{10,11}$ observed that the surface topography could dramatically influence the behaviors of mesenchymal stem cells (MSCs); the disordered nano-pit pattern was more likely to induce osteogenic differentiation than the symmetric and random nano-pit arrays. However, most of the currently successful technologies (eg, electron beam lithography, ${ }^{12,13}$ photolithography, ${ }^{14-17}$ soft lithography, ${ }^{18-20}$ etc.) are not suitable for BCP ceramics. Recently, Lin et $\mathrm{al}^{21}$ constructed a micro-nano-hybrid topography on hydroxyapatite (HA) bioceramics by regulating the hydrothermal reaction conditions, which could promote protein adsorption, osteoblast growth and osteogenic differentiation. Nevertheless, few research concerns the construction of micro-nano topography on porous BCP ceramics to improve their biological properties, and enhancing the mechanical properties of porous BCP ceramics is scarcely studied, due to their relatively complex composition as compared to HA ceramics.

Generally, the enhancement of bioactivity and the increase of mechanical strength are a contradiction. High sintering temperature can increase mechanical strength of Ca-P ceramics, but leads to a decrease in their bioactivity due to the complete crystal structure. ${ }^{22}$ One common approach is the incorporation of reinforcing phases in the Ca-P ceramics, such as organic fibers, ${ }^{23}$ carbon nanotubes, ${ }^{24}$ diopside whiskers ${ }^{25}$ and so on. However, the reinforcing phases are generally bioinert and undegradable, which might severely debase their bioactivity. Several researchers also reported that HA fibers or whiskers may be used as reinforcement, ${ }^{26,27}$ but the hybrid whisker reinforcement method has certain disadvantages, such as the easy agglomeration, the uneven distribution and the not significant enhancement of mechanical property. ${ }^{27,28}$ Therefore, it is urgent to seek a route to enhance the mechanical property and biological performance of $\mathrm{BCP}$ ceramics simultaneously. Our previous studies fabricated three-dimensional whisker-covered Ca-P ceramics by hydrothermal treatment, and found the whisker construction could increase the mechanical strength of ceramics. ${ }^{29,30}$ But the effect of hydrothermal media on the in-situ whisker growth has not been studied yet.

In this study, we proposed a strategy to construct the in-situ whisker on BCP ceramics through different hydrothermal treatments. The effects of different hydrothermal media on the surface morphology, phase composition and mechanical property of BCP ceramics were firstly investigated. Then, the effects of the in-situ whisker on the in vitro biological performances of BCP ceramics were evaluated, including the cell proliferation, spreading and osteoblastic activity of BMSCs, as well as bone-like apatite formation. The goal of this study is to realize the simultaneous enhancements of biological performances and mechanical properties of $\mathrm{BCP}$ ceramics through the in-situ whisker growth.

\section{Materials and Methods Materials Preparation}

BCP powder $(\mathrm{HA} / \beta-\mathrm{TCP}=20 / 80)$ was synthesized by a wet chemical method in the National Engineering Research Center for Biomaterials of Sichuan University, China. ${ }^{30}$ Briefly, (NH4) $)_{2} \mathrm{HPO}_{4}$ solution $\left(0.77 \quad \mathrm{~mol} \quad \mathrm{~L}^{-1}\right)$ was dropped slowly into the same volume of $\mathrm{Ca}\left(\mathrm{NO}_{3}\right)_{2}$ solution $\left(0.50 \mathrm{~mol} \mathrm{~L}{ }^{-1}\right)$ under stirring at $60{ }^{\circ} \mathrm{C}$. The $\mathrm{pH}$ of the solution was maintained at 9.0 by addition of $\mathrm{NH}_{3} \cdot \mathrm{H}_{2}$ $\mathrm{O}$ solution. Then the reaction precipitate was collected, washed, dried and crushed into powder. The porous structure was made by hydrogen peroxide $\left(\mathrm{H}_{2} \mathrm{O}_{2}\right)$ gas foaming method, and the green bodies were sintered at $1100{ }^{\circ} \mathrm{C}$ for $2 \mathrm{~h}$ to obtain the porous BCP ceramics (heating rate of $5{ }^{\circ} \mathrm{C}$ $\mathrm{min}^{-1}$ ). Then, the porous BCP ceramics were put into the Teflon autoclaves with different hydrothermal media (with the solid-liquid ratio of 1:100), which was kept at $180{ }^{\circ} \mathrm{C}$ in an oven. For nitric acid $\left(\mathrm{HNO}_{3}, \mathrm{pH}=4\right)$ solution treatment group, the reaction duration was $12 \mathrm{~h}$, the obtained samples were denoted as $\mathrm{BCP}-\mathrm{HNO}_{3}$. For citric acid $(\mathrm{pH}=4)$ solution treatment group, the reaction duration was $12 \mathrm{~h}$, the obtained samples were denoted as BCP-Citric. For sodium hydroxide $(\mathrm{NaOH}, \mathrm{pH}=10)$ solution treatment group, the reaction duration was $12 \mathrm{~h}$, the obtained samples were denoted as BCP$\mathrm{NaOH}$. For calcium chloride $\left(\mathrm{CaCl}_{2}, 0.2 \mathrm{~mol} \mathrm{~L}^{-1}\right)$ solution 
treatment group, the reaction duration was $24 \mathrm{~h}$, the obtained samples were denoted as $\mathrm{BCP}-\mathrm{CaCl}_{2}$. For trisodium phosphate $\left(\mathrm{Na}_{3} \mathrm{PO}_{4}, 0.2 \mathrm{~mol} \mathrm{~L}{ }^{-1}\right)$ solution treatment group, the reaction duration was $24 \mathrm{~h}$, the obtained samples were denoted as $\mathrm{BCP}-\mathrm{Na}_{3} \mathrm{PO}_{4}$. For comparison, the initial porous $\mathrm{BCP}$ ceramics without hydrothermal treatment were used as control group, which were denoted as BCP-C. After hydrothermal treatments, the ceramics were taken out, gently washed with deionized water and dried at $60{ }^{\circ} \mathrm{C}$. All the stated chemicals used were of analytical reagent grade from Kelong Chemical Co. (Chengdu, China) without further treatments. The sketch map illustrating the in-situ whisker growth on BCP ceramics with different hydrothermal treatments was exhibited in Scheme 1.

\section{Material Characterization}

The surface morphology of the in-situ whiskers on porous BCP ceramics was observed by scanning electron microscopy (SEM, JSE-5900LV, Japan). The grain size, whisker diameter and length were analyzed by Image-Pro Plus (IPP, Media Cybernetic, Maryland, USA) 6.0 software. The phase composition of samples was characterized by X-ray diffraction (XRD, Philips X'Pert 1 X-ray diffractometer) with $\mathrm{CuK} \alpha$ radiation at a current of $20 \mathrm{~mA}$ and voltage of 30 $\mathrm{kV}$, and the obtained peaks were compared with standard references for HA (JCPDS 09-0432) and $\beta$-TCP (JCPDS 09-0169). The phase ratios of the HA phase and $\beta$-TCP phase in the samples were calculated by the indexes mentioned before. ${ }^{31}$ The lattice parameters (a, b and $\left.c\right)$ and cell volume $(V)$ of the HA phase and $\beta$-TCP phase in the samples were separately analyzed by using the UnitCell program mentioned before. ${ }^{32,33}$ The standard crystallographic data for the refinement of HA and $\beta$-TCP were as previously published, ${ }^{34-36}$ using the space groups of the HA structure $\left(\mathrm{P} 63 / \mathrm{m}\right.$, No.176, $\left.\mathrm{a}=9.424 \AA, \mathrm{c}=6.879 \AA, \mathrm{V}=529.086 \AA^{3}\right)$ and the $\beta$-TCP structure (R3c, No.161, $\mathrm{a}=10.439 \AA, \mathrm{c}=37.375 \AA$, $\mathrm{V}=3527.2 \AA^{3}$ ), respectively. Moreover, the functional groups of the samples were identified by Fourier transform infrared spectroscopy (FT-IR, Perkin-Elmer Spectrum one B, PerkinElmer Inc., Walthm, Massachusetts, USA) and scanned from $4000 \mathrm{~cm}^{-1}$ to $500 \mathrm{~cm}^{-1}$. The compress strengths of the obtained BCP ceramics with a cylindrical shape $(\Phi 5 \times 7.5 \mathrm{~mm})$ were tested by Precision Universal Tester (Autograph AG-X, Japan), the loading rates was $1 \mathrm{~mm} \min ^{-1}$ and each group included three parallel specimens.

\section{Cell Spreading and Proliferation}

Mouse bone marrow-derived BMSCs (Cyagen Biosciences, Guangzhou, China) were seeded on the sterilized ceramic samples (25 30 kGy G-ray irradiation) in 48 -well plates at a density of $1 \times 10^{4}$ cell per well following the similar procedures reported previously. ${ }^{32}$ The cells were cultured with $\alpha$-minimum essential medium $(\alpha-$
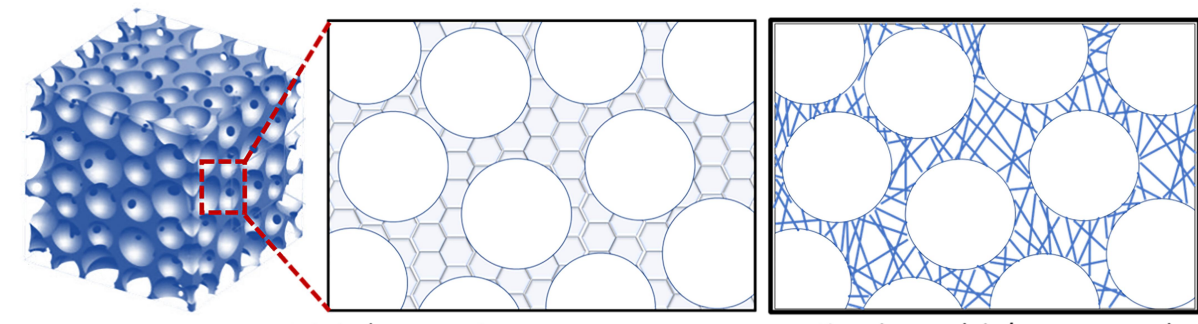

Initial ceramics

In-situ whisker growth

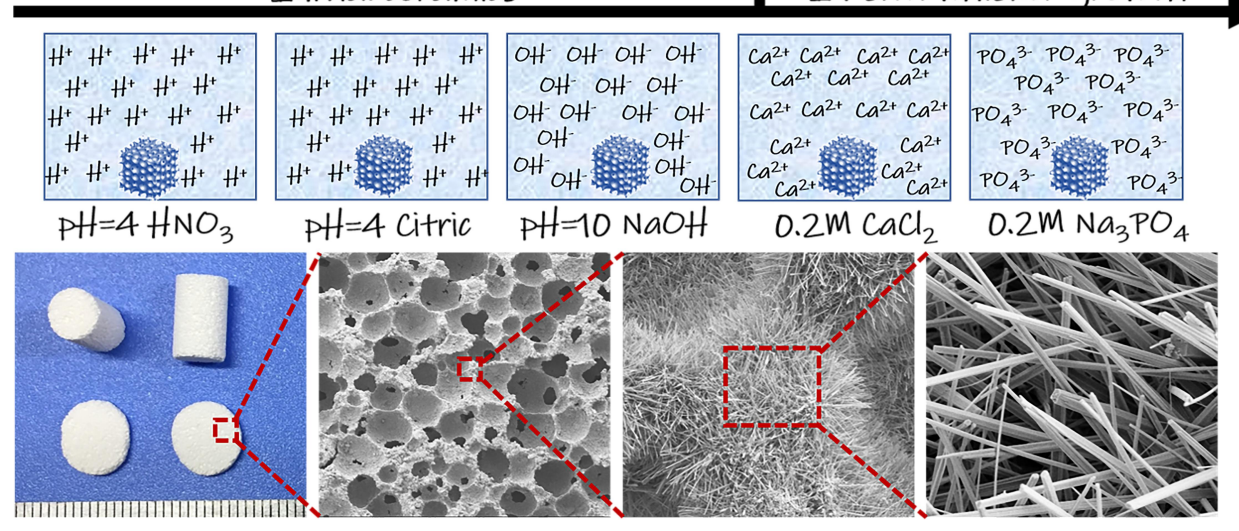

Scheme I Sketch map illustrating the in-situ whisker growth on BCP ceramics with different hydrothermal treatments. 
MEM, Hyclone, Logan, Utah, USA) containing 10\% fetal bovine serum (FBS, Gibco, Grand Island, New York, USA) and $1 \%$ antibiotics (penicillin/streptomycin) under $5 \% \mathrm{CO}_{2}$ atmosphere at $37^{\circ} \mathrm{C}$. Fluorescein diacetate (FDA, Sigma-Aldrich Co., San Francisco, California, USA) and propidiumiodide (PI, Sigma-Aldrich Co.) were used to stain the attached cells, and then visualized by a confocal laser scanning microscopy (CLSM, TCS SP5, Leica). The viability of BMSCs on the samples $(n=5)$ was quantified by using AlamarBlue assay. After culturing for 2 days, each group was fixed with $2 \%$ glutaraldehyde at $4{ }^{\circ} \mathrm{C}$ overnight, washed three times with PBS, and then dehydrated by increasing the gradient of ethanol. Finally, these samples were dried using a critical point drier (HCP-2, Hitachi Ltd., Tokyo, Japan), and observed with SEM.

\section{Alkaline Phosphatase (ALP) Activity}

At each time point, BMSCs cultured on each sample were lysed by RIPA lysate (Boster, Wuhan, China). Following the manufacturer's instruction, the ALP activity of the BMSCs cultured on each group was tested colorimetrically by Alkaline Phosphatase Assay Kit (Beyotime, Shanghai, China), based on the conversion of p-nitrophenyl phosphate (pNPP) to p-nitrophenol after incubation at $37^{\circ} \mathrm{C}$ for $30 \mathrm{~min}$. The results were normalized to the total protein content, which was measured by Pierce BCA protein assay kit (Themofisher Scientific, Waltham, MA, USA). The test was carried out with triplicate samples and each sample was tested three times.

\section{SBF Immersing}

SBF was prepared according to the previous literature, ${ }^{33,34}$ which with $\mathrm{Na}^{+}\left(142.0 \mathrm{mmol} \mathrm{L}^{-1}\right), \mathrm{K}^{+}\left(5.0 \mathrm{mmol} \mathrm{L}^{-1}\right), \mathrm{Ca}^{2+}$

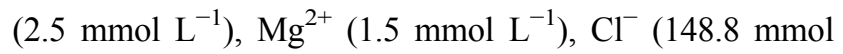

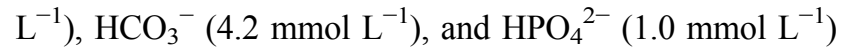
was buffered at $\mathrm{pH} 7.40$ by Tris buffer $\left(50 \mathrm{mmol} \mathrm{L}^{-1}\right)$ and $\mathrm{HCl}\left(45 \mathrm{mmol} \mathrm{L}{ }^{-1}\right)$. First, the obtained samples were immersed into SBF for 3 days at $37{ }^{\circ} \mathrm{C}$. Then, the samples were taken out, gently washed with the deionized water and dried in an oven. Finally, SEM was used to observe the formation of bone-like apatite on the samples.

\section{Statistical Analysis}

All quantitative results were obtained from at least triplicate measurements $(n \geq 3)$. Statistical analysis of the data was performed using one-way analysis of variance (ANOVA) by using SPSS 11.0 software (SPSS Inc.,
Chicago, IL, USA). Statistical significance was assumed at $p<0.05$.

\section{Results SEM Images}

As shown in Figure 1A, the initial BCP ceramics (BCP-C) exhibited typical ceramic morphology, obvious grain boundaries were distributed among the ceramic grains, and the grain size of BCP-C was $1.33 \pm 0.21 \mu \mathrm{m}$. After hydrothermal treatments, the morphologies of $\mathrm{BCP}$ ceramics underwent dramatic changes, all the skeletons of $\mathrm{BCP}-\mathrm{HNO}_{3}$ (Figure 1B), BCP-Citric (Figure 1C), BCP-NaOH (Figure 1D), BCP$\mathrm{CaCl}_{2}$ (Figure 1E) and $\mathrm{BCP}-\mathrm{Na}_{3} \mathrm{PO}_{4}$ (Figure 1F) were almost completely transformed into the whisker structure (SEM images of their cross-sections were shown in Supporting information S-1). However, the morphologies of whiskers were different, the whisker lengths (Figure 1G) of BCP$\mathrm{NaOH}(15.94 \pm 2.86 \mu \mathrm{m}), \mathrm{BCP}-\mathrm{Citric}(11.23 \pm 1.39 \mu \mathrm{m})$ and $\mathrm{BCP}-\mathrm{CaCl}_{2}(13.19 \pm 2.28 \mu \mathrm{m})$ were longer those of $\mathrm{BCP}$ $\mathrm{HNO}_{3}(8.46 \pm 1.65 \mu \mathrm{m})$ and $\mathrm{BCP}-\mathrm{Na}_{3} \mathrm{PO}_{4}(2.33 \pm 0.56 \mu \mathrm{m})$, whereas the whisker diameters (Figure $1 \mathrm{H}$ ) had no obvious difference except $\mathrm{BCP}-\mathrm{Na}_{3} \mathrm{PO}_{4}$, which had the smallest whisker diameter among the five groups. Moreover, the whiskers in $\mathrm{BCP}-\mathrm{Na}_{3} \mathrm{PO}_{4}$ were hollow, whereas the others were solid. The length-diameter ratios of the in-situ whiskers were also calculated, and shown in Figure 1I, BCP-NaOH had the largest length-diameter ratio of 18.53 , while BCP$\mathrm{Na}_{3} \mathrm{PO}_{4}$ had the least of 3.95 among the obtained samples.

\section{XRD Patterns and FT-IR Spectra}

XRD patterns of BCP ceramics with different hydrothermal treatments are shown in Figure 2A, and their diffraction peaks were compared with standard references for HA (JCPDS 09-0432) and $\beta$-TCP (JCPDS 09-0169). By calculating, the HA content in the initial BCP ceramic (BCPC) was $16.76 \%$ (list in Table 1), which was consistent with the phase composition of the initial powder. After hydrothermal treatments, the HA phase ratios in the samples were increased remarkably. For BCP- $\mathrm{HNO}_{3}, \mathrm{BCP}-\mathrm{Citric}$, $\mathrm{BCP}-\mathrm{NaOH}$ and $\mathrm{BCP}-\mathrm{CaCl}_{2}$, the samples were only composed of HA phase, possibly because $\beta$-TCP phase in these samples might transfer into HA phase during the hydrothermal reaction. However, $\beta$-TCP phase was still observed in $\mathrm{BCP}-\mathrm{Na}_{3} \mathrm{PO}_{4}$, demonstrating that the hydrothermal solution of $\mathrm{Na}_{3} \mathrm{PO}_{4}$ might inhibit the phase transformation of $\beta$-TCP to HA. Moreover, the lattice parameters (ie, the unit cell lengths $a, b$, and cell volume 


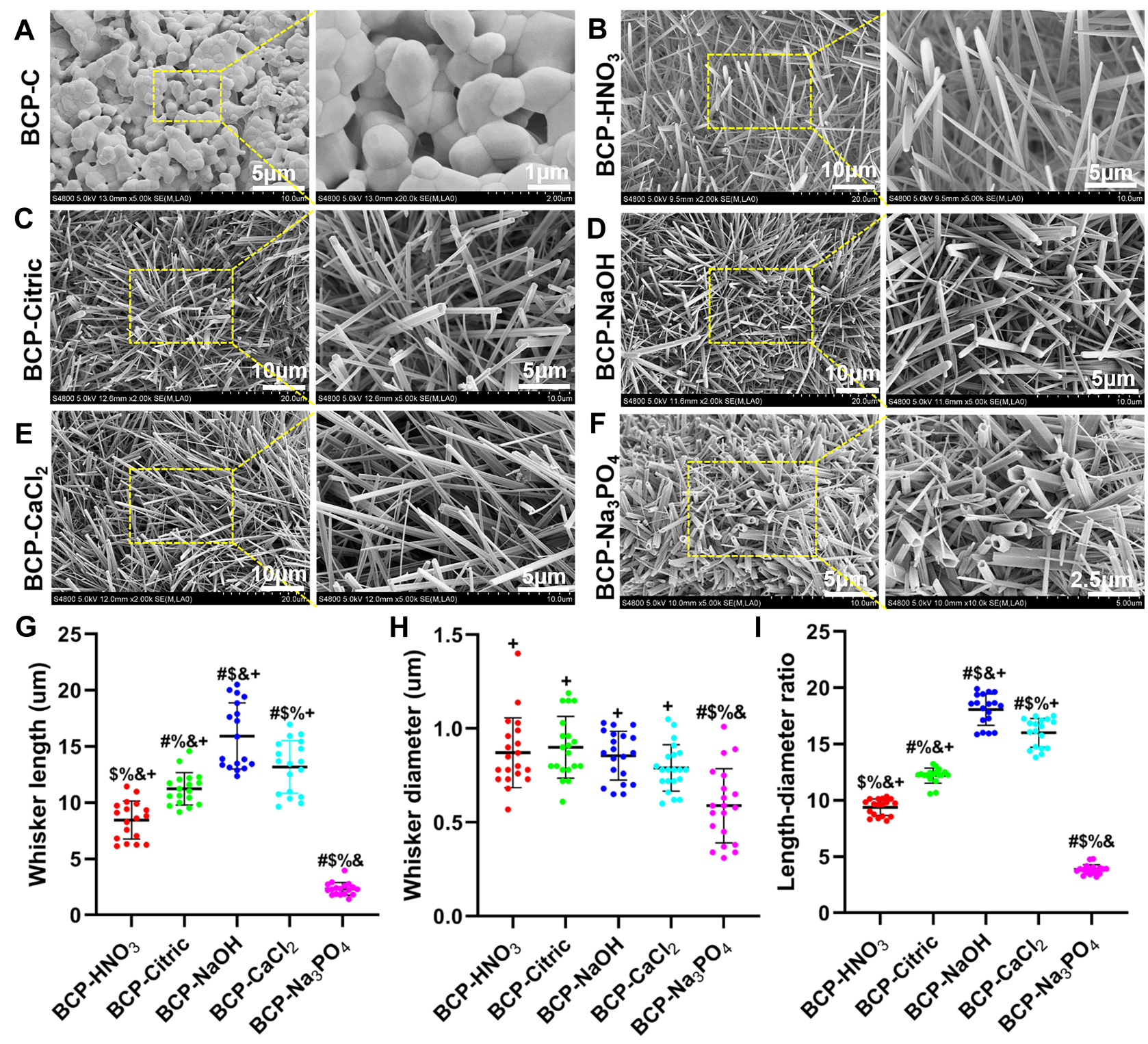

Figure I SEM images (A) BCP-C; (B) BCP-HNO ${ }_{3}$; (C) BCP-Citric; (D) BCP-NaOH; (E) BCP- $\mathrm{CaCl}_{2}$; (F) $\left.\mathrm{BCP}_{-} \mathrm{Na}_{3} \mathrm{PO}_{4}\right)$, whisker lengths (G), whisker diameters (H) and length-diameter ratios (I) of the obtained $\mathrm{BCP}$ samples. ${ }^{\#} p<0.05$ vs $\mathrm{BCP}_{-} \mathrm{HNO}_{3}$ group, ${ }^{\$} p<0.05$ vs $\mathrm{BCP}-\mathrm{Citric}$ group, ${ }^{\%} p<0.05$ vs $\mathrm{BCP}-\mathrm{NaOH}$ group, ${ }^{\&} p<0.05$ vs $\mathrm{BCP}-\mathrm{CaCl}{ }_{2}$ group, ${ }^{+} p<0.05$ vs $\mathrm{BCP}-\mathrm{Na}_{3} \mathrm{PO}_{4}$ group.

$V$ ) of the HA phase of BCP ceramics after hydrothermal treatments were all higher than those in BCP-C (listed in Table 1). In addition, the crystal sizes calculated from the HA peak (002) at $2 \theta=25.8^{\circ}$ also increased remarkably after hydrothermal treatments as comparing with the initial BCP ceramics of BCP-C. The changes of lattice parameters and the increments of crystal sizes further proved the orientated growth of HA crystals during the hydrothermal reactions of $\mathrm{BCP}$ ceramics.

FT-IR spectra of BCP ceramics with different hydrothermal treatments was also characterized (Figure 2B). All the BCP samples exhibited the similar exhibited the characteristic bands of the phosphate groups of the apatite about 550 and $600 \mathrm{~cm}^{-1}, 960 \mathrm{~cm}^{-1}$, and 1020 $-1120 \mathrm{~cm}^{-1}$. The bands at 630 and $3540 \mathrm{~cm}^{-1}$ were assigned to hydroxide group. The broad bands in the regions $1600-1700 \mathrm{~cm}^{-1}$ and $3200-3600 \mathrm{~cm}^{-1}$ corresponded to adsorbed water. $^{35-37}$ By comparing, it could be observed that the absorption peaks of hydroxide group $\left(630 \mathrm{~cm}^{-1}\right)$ in $\mathrm{BCP}-\mathrm{Citric}, \mathrm{BCP}-\mathrm{NaOH}$ and $\mathrm{BCP}-\mathrm{CaCl}_{2}$ were stronger than those in $\mathrm{BCP}-\mathrm{C}$ and $\mathrm{BCP}-\mathrm{Na}_{3} \mathrm{PO}_{4}$. That might be due to the content of $\mathrm{HA}$ phase in BCP-Citric, $\mathrm{BCP}-\mathrm{NaOH}$ and $\mathrm{BCP}-\mathrm{CaCl}_{2}$ was higher than BCP-C and $\mathrm{BCP}-\mathrm{Na}_{3} \mathrm{PO}_{4}$. 

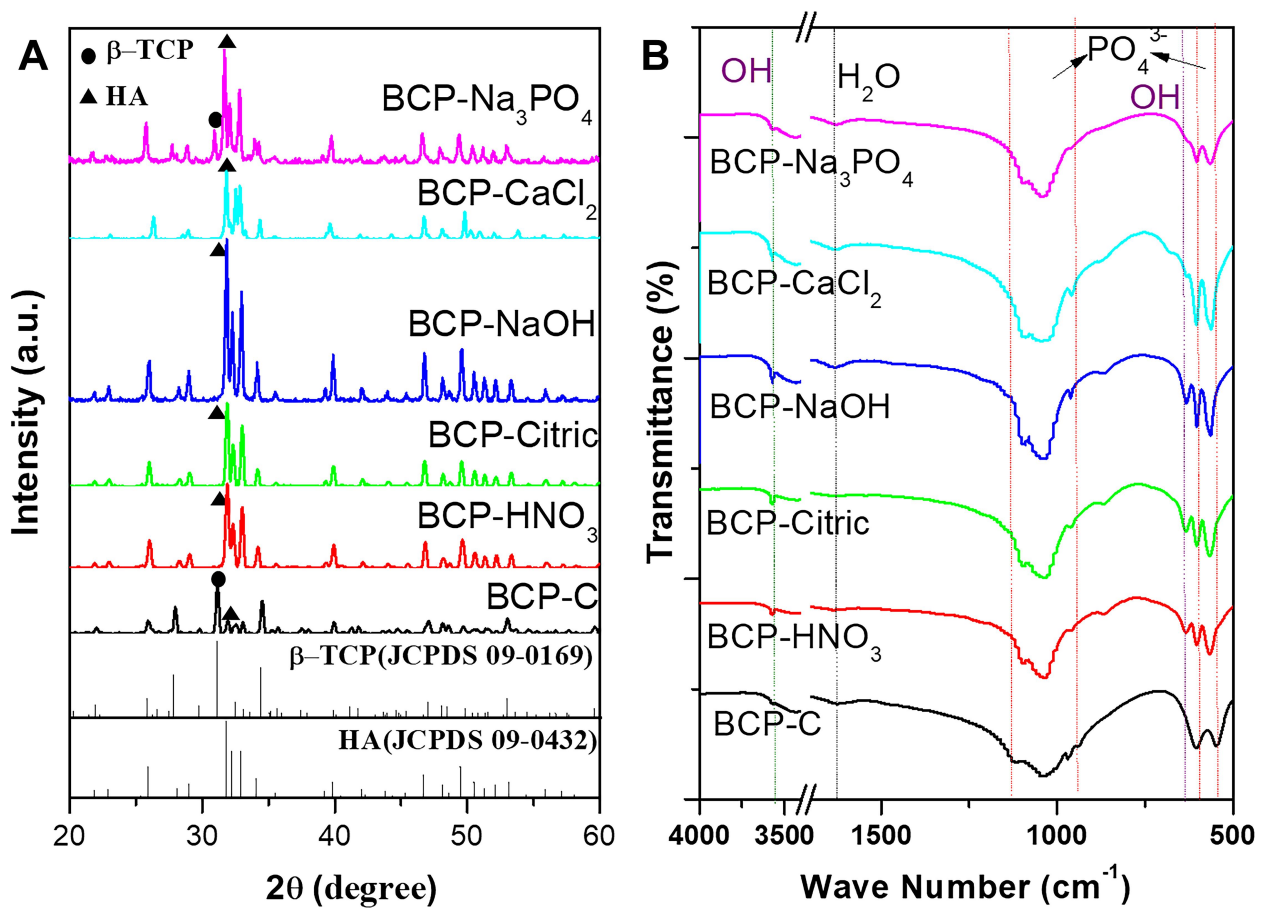

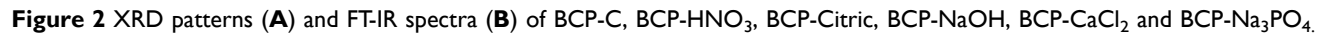

\section{Mechanical Properties}

The stress-strain curves of the obtained BCP samples indicated their typically brittle fracture behaviors (Figure 3A).

Table I Summary of Phase Ratios, Lattice Parameters and Crystal Sizes Calculated from the XRD Patterns from the HA Phase and the $\beta$-TCP Phase in BCP-C, BCP-HNO, BCP-Citric, BCP-NaOH, BCP-CaCl 2 and BCP-Na ${ }_{3} \mathrm{PO}_{4}$

\begin{tabular}{|c|c|c|c|c|c|c|}
\hline Samples & Phase & $\begin{array}{l}\text { Ratio } \\
\text { (\%) }\end{array}$ & $\begin{array}{l}a=b \\
(\mathrm{~nm})\end{array}$ & $\begin{array}{l}\text { c } \\
(\mathrm{nm})\end{array}$ & $\begin{array}{l}V \\
\left(\mathrm{~nm}^{3}\right)\end{array}$ & $\begin{array}{l}\text { XS } \\
(\mathrm{nm})\end{array}$ \\
\hline \multirow[t]{2}{*}{ BCP-C } & $\mathrm{HA}$ & 16.76 & 0.9368 & 0.6875 & 0.5226 & 19.2 \\
\hline & $\beta-\mathrm{TCP}$ & 83.24 & 1.0390 & 3.7367 & 3.4932 & - \\
\hline BCP- & $\mathrm{HA}$ & 100 & 0.9403 & 0.6859 & 0.5272 & 25.9 \\
\hline $\mathrm{HNO}_{3}$ & $\beta-\mathrm{TCP}$ & - & - & - & - & - \\
\hline BCP- & $\mathrm{HA}$ & 100 & 0.9414 & 0.6867 & $0.527 \mid$ & 35.0 \\
\hline Citric & $\beta-\mathrm{TCP}$ & - & - & - & - & - \\
\hline BCP- & $\mathrm{HA}$ & 100 & 0.9396 & 0.6858 & 0.5244 & 27.6 \\
\hline $\mathrm{NaOH}$ & $\beta-\mathrm{TCP}$ & - & - & - & - & - \\
\hline BCP- & $\mathrm{HA}$ & 100 & 0.9473 & 0.6865 & 0.5335 & 37.6 \\
\hline $\mathrm{CaCl}_{2}$ & $\beta$-ТCP & - & - & - & - & - \\
\hline BCP- $\mathrm{Na}_{3}$ & HA & 84.32 & 0.9426 & 0.6890 & 0.5301 & 26.6 \\
\hline $\mathrm{PO}_{4}$ & $\beta$-TCP & 15.68 & 1.0428 & 3.7360 & 3.5183 & - \\
\hline \multirow[t]{2}{*}{ Standard } & $\mathrm{HA}$ & - & 0.9418 & 0.6884 & 0.5288 & - \\
\hline & $\beta$-ТCP & - & 1.0429 & 3.7380 & 3.7380 & - \\
\hline
\end{tabular}

Abbreviations: $B C P$, biphasic calcium phosphate; Ca-P, calcium phosphate; ALP, alkaline Phosphatase; SBF, simulated body fluid.
After hydrothermal treatments, the maximum compressive stress of BCP-HNO ${ }_{3}, \mathrm{BCP}-\mathrm{Citric}, \mathrm{BCP}-\mathrm{NaOH}, \mathrm{BCP}-\mathrm{CaCl}_{2}$ and $\mathrm{BCP}-\mathrm{Na}_{3} \mathrm{PO}_{4}$ increased remarkably as comparing with BCP-C. Moreover, the compress strengths and elastic modulus of the obtained BCP ceramics were also calculated and exhibited in Figure 3B. The compress strengths of BCP$\mathrm{HNO}_{3}, \mathrm{BCP}-\mathrm{Citric}, \mathrm{BCP}-\mathrm{NaOH}, \mathrm{BCP}-\mathrm{CaCl}_{2}$ and BCP-Na $\mathrm{PO}_{4}$ were two to four times higher than the initial sample (BCP-C), and $\mathrm{BCP}-\mathrm{CaCl}_{2}$ had the highest compress strength of $5.34 \pm 0.35 \mathrm{MPa}$ among the obtained $\mathrm{BCP}$ samples. In addition, the in-situ whisker growth could also increase the elastic modulus of the BCP ceramics, which were three to six times higher than BCP-C. Similarly, BCP$\mathrm{CaCl}_{2}$ also had the highest elastic modulus of $140.17 \pm 44.36$ $\mathrm{MPa}$ among the six groups. These results indicated that the in-situ whisker growth could significantly increase the mechanical properties of BCP ceramics.

\section{Cell Viability and Spreading}

CLSM observations (Figure 4A-F) showed that BMSCs seeded on all the BCP groups spread well and presented a mass of live cells (stained green by FDA) with few dead cells (stained red by PI) after 3 days of culture. All the $\mathrm{BCP}$ groups could promote cell growth, and the extensive cell-cell interactions were observed at day 3 . Cell viability of BMSCs seeded on $\mathrm{BCP}$ groups was measured by AlamarBlue assay (Figure 4G-H). After 3 

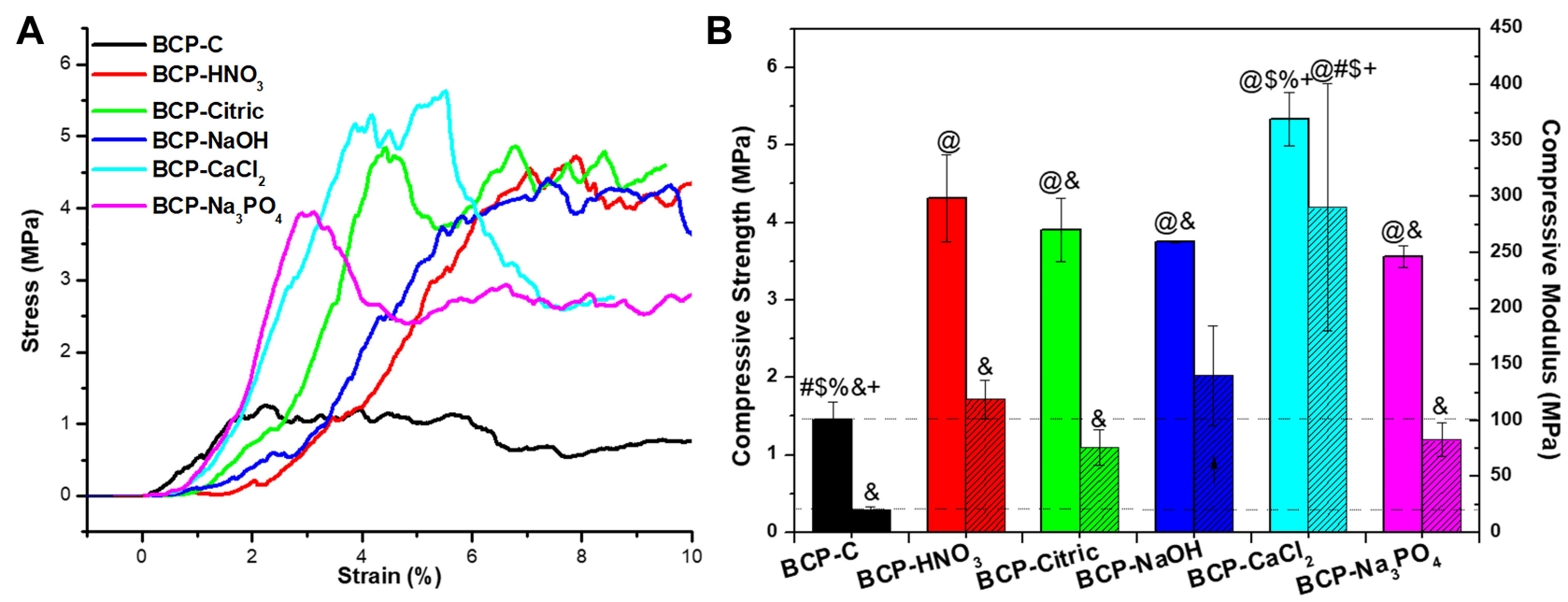

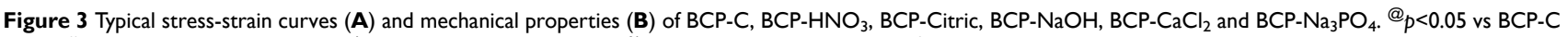
group, ${ }^{\#} p<0.05$ vs $B C P-H_{3 N O}$ group, ${ }^{\$} p<0.05$ vs $\mathrm{BCP}-$ Citric group, ${ }^{\%} p<0.05$ vs $\mathrm{BCP}-\mathrm{NaOH}$ group, ${ }^{\&} p<0.05$ vs $\mathrm{BCP}_{-} \mathrm{CaCl}_{2}$ group, ${ }^{+} p<0.05$ vs $\mathrm{BCP}-\mathrm{Na}{ }_{3} \mathrm{PO}{ }_{4}$ group.

and 5 days of culture, BMSCs on the BCP ceramics with different hydrothermal treatments had similar cell viability as comparing to $\mathrm{BCP}-\mathrm{C}$, indicating the in-situ whisker growth had no effect on the cell viability of BCP ceramics.

SEM images further confirmed that BMSCs attached and spread well on the obtained BCP samples (Figure 5AF). The cells exhibited a typical spindle-like morphology, and abundant filopodia were outstretched to tightly grasp the ceramic grains or whiskers. It could be observed that the elongated whiskers of BCP- $\mathrm{HNO}_{3}, \mathrm{BCP}-\mathrm{Citric}$, BCP$\mathrm{NaOH}$ and $\mathrm{BCP}-\mathrm{CaCl}_{2}$ might puncture the BMSCs. While cells attached and spread better on $\mathrm{BCP}-\mathrm{Na}_{3} \mathrm{PO}_{4}$ (Figure $5 \mathrm{G}$ ), it had the relatively larger cell spreading area $\left(454.83 \pm 58.77 \mu^{2}\right)$ than BCP-C $(342.71 \pm 31.71$ $\left.\mu \mathrm{m}^{2}\right)$, BCP-HNO $\left(270.84 \pm 28.20 \mu \mathrm{m}^{2}\right)$ and BCP-Citric (263.45 $\pm 2.55 \mu \mathrm{m}^{2}$ ), demonstrating that the hollow whiskers were beneficial to cell spreading.

\section{Alkaline Phosphatase (ALP) Activity}

ALP activity in BMSCs cultured on the obtained BCP samples for 7 days was also evaluated (Figure 6), which was an important predictor of osteogenic lineage commitment and a specific inducer of bone formation. Similar with the initial sample (BCP-C), almost all BCP ceramics with in-situ whisker growth had relatively high intracellular ALP activity. Moreover, the ALP activity of BCP$\mathrm{CaCl}_{2}$ group was higher than $\mathrm{BCP}-\mathrm{C}$ and $\mathrm{BCP}-\mathrm{HNO}_{3}$ group, and $\mathrm{BCP}-\mathrm{NaOH}$ had the highest intracellular ALP activity among the obtained BCP ceramics.

\section{Bone-Like Apatite Formation}

The surface topographies of $\mathrm{BCP}-\mathrm{C}, \mathrm{BCP}-\mathrm{HNO}_{3}, \mathrm{BCP}-$ Citric, $\mathrm{BCP}-\mathrm{NaOH}, \mathrm{BCP}-\mathrm{CaCl}_{2}$ and $\mathrm{BCP}-\mathrm{Na}_{3} \mathrm{PO}_{4}$ after immersing in $\mathrm{SBF}$ for 3 days were shown in Figure 7A-F. It could be observed that all the samples after hydrothermal treatments could facilitate bone-like apatite formation on their surfaces as comparing to the initial sample (BCP-C). Among them, the bone-like apatite formation ability of BCP$\mathrm{Na}_{3} \mathrm{PO}_{4}$ seemed strongest, whose surface was totally covered with bone-like apatite deposit. The relatively high bone-like apatite formation abilities indicated that the hydrothermal treatments might increase the bioactivity of BCP ceramics.

\section{Discussion}

Further enhancing the bioactivity to meet the requirements of regenerative medicine is an eternal topic when designing $\mathrm{Ca}-\mathrm{P}$ ceramics. Construction of specific topography on biomaterials is quite an effective route to regulate the protein adsorption and cellular behaviors, and further improve their biological performances. Our previous studies have certified that the osteoinductivity of BCP ceramics could be heightened by the design of nano-topography. ${ }^{38-40}$ However, to achieve the simultaneous enhancements of mechanical properties and biological performances of Ca-P ceramics has not achieved right now. Therefore, the present study attempted to solve the paradox by constructing the in-situ whisker on BCP ceramics.

After hydrothermal treatments, the surface topographies of BCP ceramics underwent dramatic changes, obvious in-situ whiskers were growing in the ceramic matrix. In the hydrothermal process, BCP ceramics 

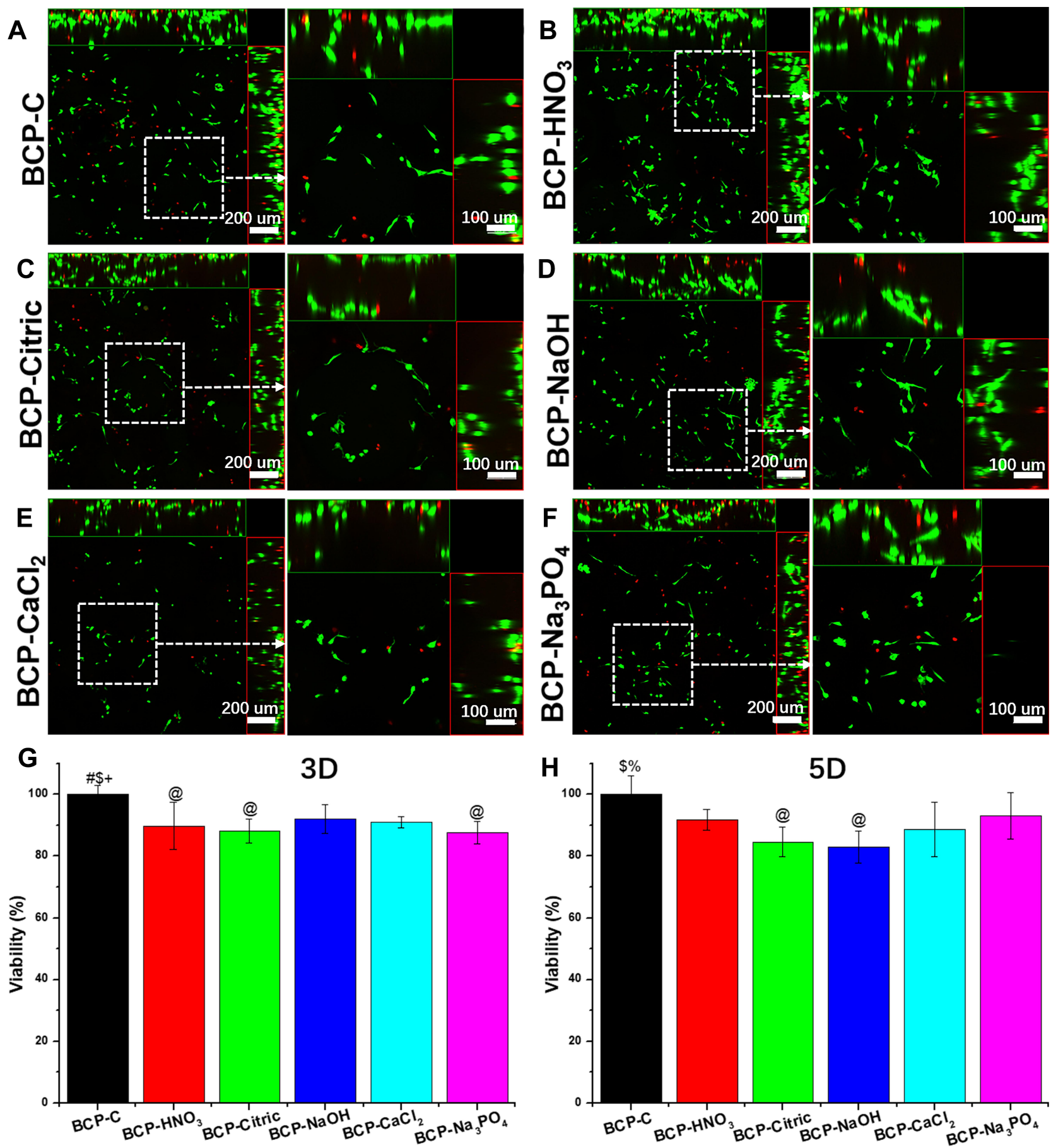

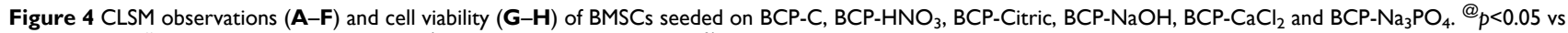
BCP-C group, ${ }^{\#} p<0.05$ vs $\mathrm{BCP}-\mathrm{HNO}_{3}$ group, ${ }^{\$} p<0.05$ vs BCP-Citric group, ${ }^{\%} p<0.05$ vs $\mathrm{BCP}-\mathrm{NaOH}$ group, ${ }^{+} p<0.05$ vs $\mathrm{BCP}^{\mathrm{N}} \mathrm{Na}{ }_{3} \mathrm{PO} \mathrm{O}_{4}$ group.

gradually released $\mathrm{Ca}_{2}{ }^{+}$and $\mathrm{PO}_{4}{ }^{3-}$ ions. When the ion concentration in the solution reached saturation, the dissolved ions could precipitate to form in-situ whiskers. ${ }^{30}$ By adjusting the hydrothermal conditions, especially the hydrothermal media, different morphologies and compositions of the in-situ whiskers were obtained. For BCP$\mathrm{HNO}_{3}, \quad$ BCP-Citric, BCP-NaOH, BCP-CaCl 2 , their whiskers lengths and length-diameter ratios were significantly higher than $\mathrm{BCP}-\mathrm{Na}_{3} \mathrm{PO}_{4}$, and the morphology of whiskers in $\mathrm{BCP}-\mathrm{Na}_{3} \mathrm{PO}_{4}$ was hollow shape, whereas the others were solid (Figure 1). Moreover, the phase compositions of $\mathrm{BCP}-\mathrm{Na}_{3} \mathrm{PO}_{4}$ were still composed of HA phase and $\beta$-TCP phase, which was consistent with the initial powder. But for $\mathrm{BCP}-\mathrm{HNO}_{3}$, BCP-Citric, $\mathrm{BCP}-\mathrm{NaOH}$, and 


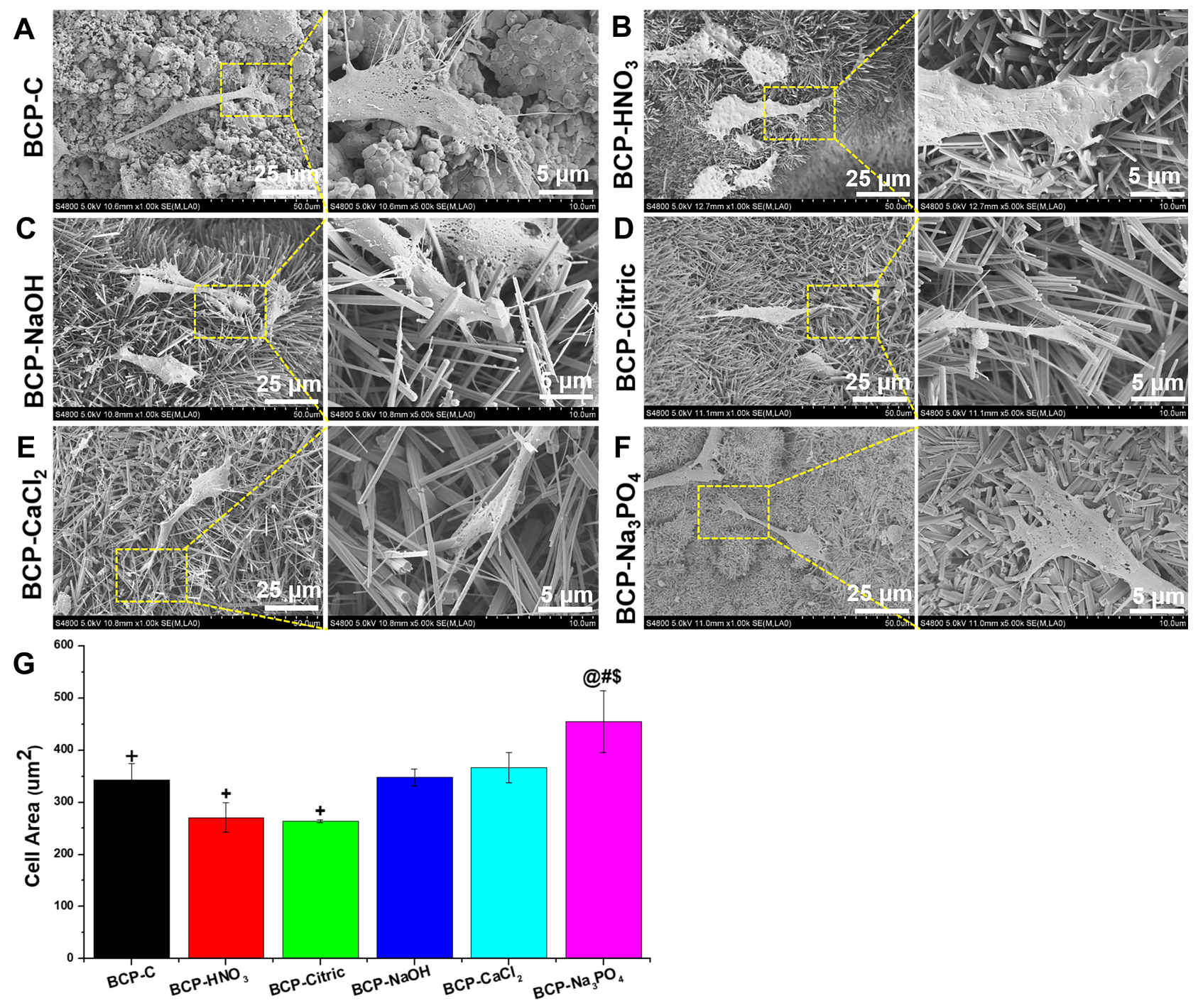

Figure 5 Cell spreading (A) BCP-C; (B) BCP-HNO ${ }_{3}$; (C) BCP-Citric; (D) BCP-NaOH; (E) BCP- $\mathrm{CaCl}_{2}$; (F) $\left.\mathrm{BCP}_{-} \mathrm{Na}_{3} \mathrm{PO}_{4}\right)$ and cell area $(\mathbf{G})$ of the obtained BCP samples.

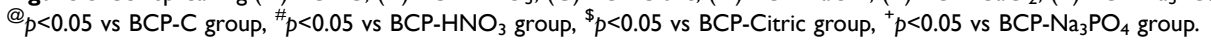

$\mathrm{BCP}-\mathrm{CaCl}_{2}$, their compositions were only composed of HA phase. It is known that HA phase is the thermodynamically stable phase, $\beta$-TCP phase in the initial BCP ceramics could transfer into HA phase during the hydrothermal process, and the hexagonal HA crystals easily grow along $c$-axis, which results into the phase transformation and whiskers growth. ${ }^{41-43}$ For $\mathrm{BCP}-\mathrm{Na}_{3} \mathrm{PO}_{4}$, the phase transformation of $\beta$-TCP phase to HA phase was inhibited due to the high concentration of $\mathrm{PO}_{4}{ }^{3-}$ ions, which could inhibit the occurrence of transformation by the chemical equilibrium theory. And $\mathrm{PO}_{4}{ }^{3-}$ ions were easily adsorbed on $a, b$ planes to form the nucleation cluster, leading to the formation of short whiskers with hollow structure (Figure 2). For the other groups, $\beta$-TCP phase could be gradually transferred to HA phase, due to
HA phase was thermodynamically stable phase, resulting in that HA phase was only phase after hydrothermal treatment. Especially, the $\mathrm{Ca}^{2+}$ ions could promote the phase transformation of $\beta$-TCP phase to HA phase in $\mathrm{CaCl}_{2}$ group. These inferences could be further certified by EDS analysis (Supporting information S-3), $\mathrm{BCP}-\mathrm{CaCl}_{2}$ had the highest $\mathrm{Ca} / \mathrm{P}$ ratio among the obtained $\mathrm{BCP}$ ceramics, due to $\mathrm{Ca}^{2+}$ might be incorporated in the ceramics during the hydrothermal treatment; whereas, $\mathrm{BCP}-\mathrm{Na}_{3} \mathrm{PO}_{4}$ group had the lowest $\mathrm{Ca} / \mathrm{P}$ ratio, due to $\mathrm{PO}_{4}{ }^{3-}$ might be incorporated in the ceramics. The orientation degree of HA crystals could further certify the changes of lattice parameters and the increments of crystal sizes calculated from the HA peak (002) at $2 \theta=25.8^{\circ}$ (Table 1). After the in-situ whisker growth, HA crystals in BCP ceramics 


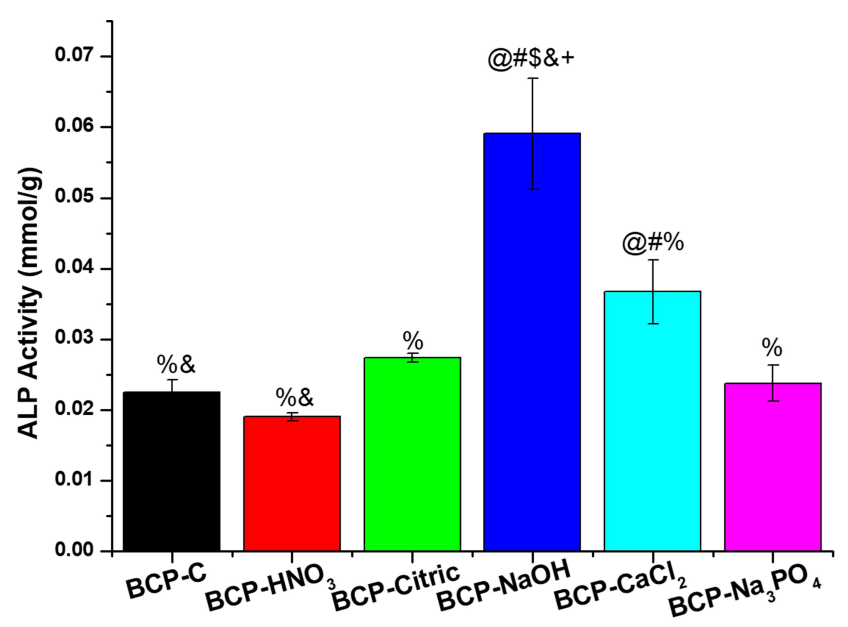

Figure 6 Intracellular ALP activity in BMSCs cultured on the obtained BCP samples. ${ }^{@} p<0.05$ vs BCP-C group, ${ }^{\#}<<0.05$ vs $B C P-H_{N O}$ group, ${ }^{\$} p<0.05$ vs BCPCitric group, ${ }^{\%} p<0.05$ vs $\mathrm{BCP}-\mathrm{NaOH}$ group, ${ }^{\circledR} p<0.05$ vs $\mathrm{BCP}-\mathrm{CaCl}_{2}$ group, ${ }^{+} p<0.05$ vs $\mathrm{BCP}-\mathrm{Na}_{3} \mathrm{PO}_{4}$ group.

rearranged and grew oriented along the $c$-axis, which resulted into the lattice distortion in the $\mathrm{BCP}$ ceramics after hydrothermal treatments. ${ }^{29,30}$ Moreover, the increasement of crystal sizes (002) further certified the oriented growth of HA crystals in BCP ceramics after hydrothermal treatments. Lin et al also observed the sharp and intensive (002) peak in the HA bioceramics after hydrothermal treatment, which indicated that HA crystals preferred to be aligned apparently along the $c$-axis. ${ }^{21}$ In addition, the growth trend of HA crystals was consistent with the whisker length as shown in Figure 1, BCP-Citric, BCP-NaOH, and $\mathrm{BCP}-\mathrm{CaCl}_{2}$ had relatively larger $\mathrm{HA}$ crystals and longer whisker lengths than $\mathrm{BCP}-\mathrm{HNO}_{3}$ and $\mathrm{BCP}-\mathrm{Na}_{3}$ $\mathrm{PO}_{4}$.

The growth of in-situ whisker could remarkably increase the mechanical strengths of BCP ceramics. In fact, whisker reinforcement is a common method to increase the mechanical strength of ceramics. As comparing with the transcrystalline crack and intercrystalline crack in BCP-C ceramics, in-situ whisker growth could change crack propagation path completely (Supporting information S-2). When a crack enters the whiskerreinforced composite, there are generally five different toughening mechanisms, including: bridging, pullout, deflection, micro cracking and pinning. ${ }^{44} \mathrm{Li}$ et $\mathrm{al}^{45}$ introduced aluminum borate whisker into porous ceramics, the tensile strength of the composite material with a whisker volume fraction of $20 \%$ can be improved by up to about $90 \%$ compared with the unreinforced matrix. However, the common whisker materials (ie, $\mathrm{SiC}$, carbon, $\mathrm{Si}_{3} \mathrm{~N}_{4}, \mathrm{Al}_{2} \mathrm{O}_{3}$, $\mathrm{ZrO}_{2}$ ) are bioinert, which might decrease the biocompatibility and bioactivity of Ca-P bioceramics. The most promising reinforcement is Ca-P whisker (for example, HA whiskers), because of the excellent biocompatibility,
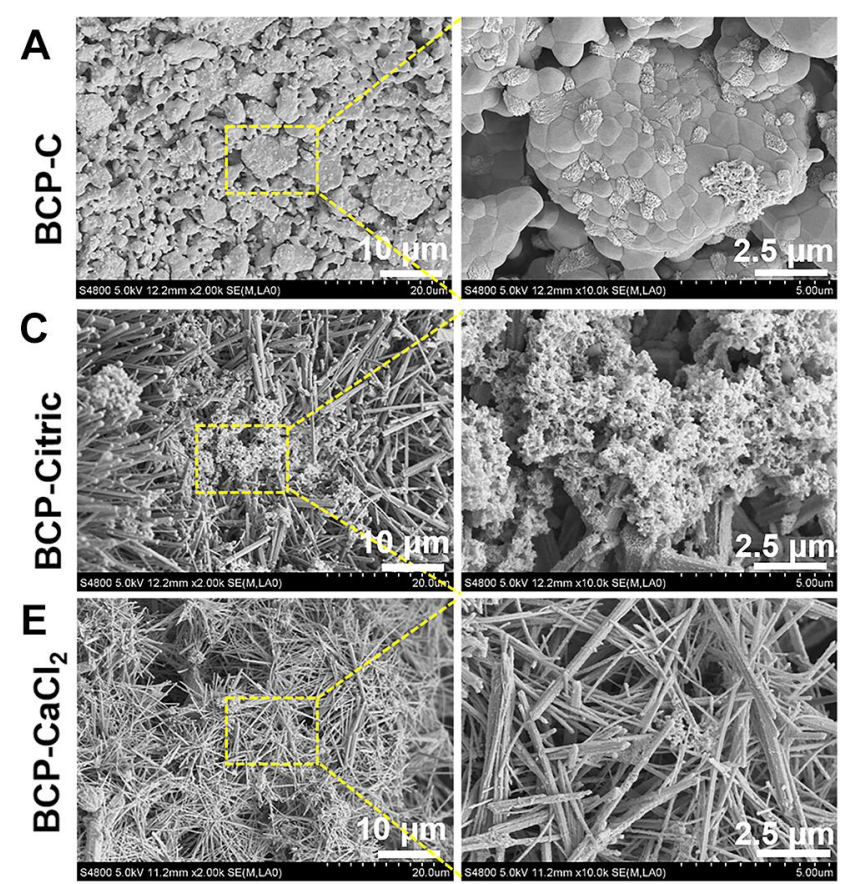
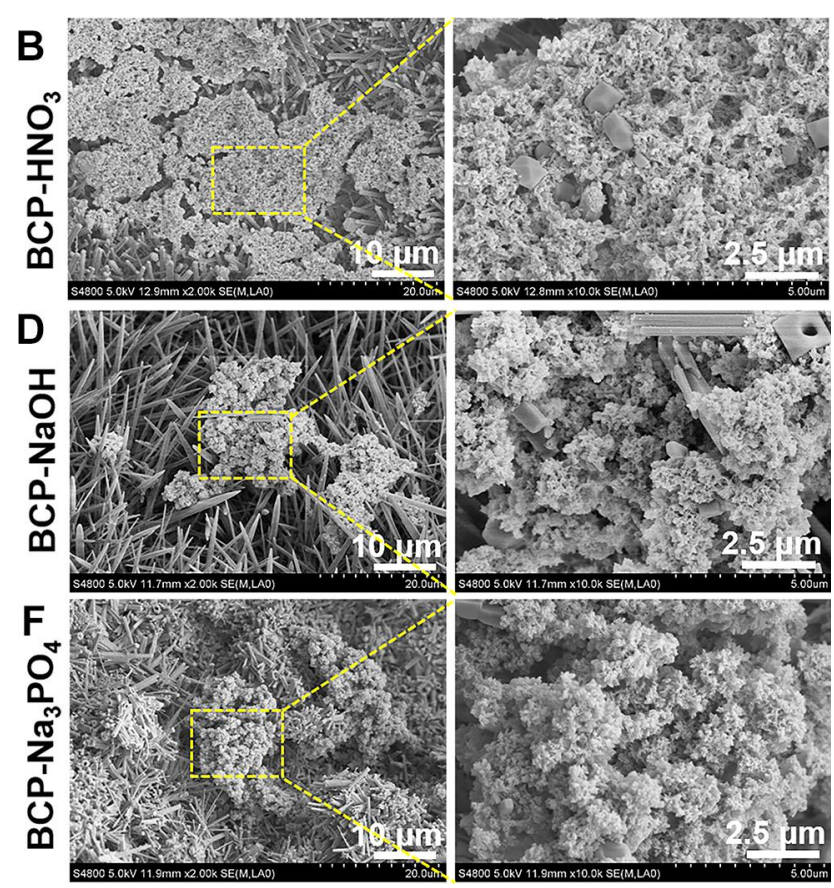

Figure 7 The surface topographies of $\mathrm{BCP}$ ceramics with different hydrothermal treatments after immersing in $\mathrm{SBF}$ for 3 days: (A) BCP-C; (B) $\mathrm{BCP}-\mathrm{HNO}{ }_{3}$; (C) $\mathrm{BCP}-\mathrm{Citric}$; (D) BCP-NaOH, (E) BCP- $\mathrm{CaCl}_{2}$; (F) $\mathrm{BCP}-\mathrm{Na}_{3} \mathrm{PO}_{4}$. 
bioactivity, and non-polluting phase composition. In the study of Suchanek et al, ${ }^{27,28}$ they fabricated HA and HA whisker composites by hydrothermal synthesis, when the content of HA whisker was $20-30 \%$, the fracture toughness of the ceramics increased $40-100 \%$; but further increasing the whisker content might decrease the mechanical properties of ceramics. That might be due to the hybrid whisker reinforcement method may cause the easy agglomeration and the uneven distribution of whiskers, which restrict the further enhancement of mechanical strength of ceramics. In the present study, the in-situ whiskers were growing on the surface and inner of $\mathrm{BCP}$ ceramics, that is, the total ceramic matrix was constituted of whiskers (Figure 1). So, the compressive strength and modulus of the BCP ceramics (Figure 3) with hydrothermal treatments increased remarkably (2.5-4 times) as compared with the initial BCP ceramics (about 1.5 MPa). Among them, $\mathrm{BCP}-\mathrm{CaCl}_{2}$ owed the highest compressive strength of $5.34 \pm 0.35 \mathrm{MPa}$ among the obtained ceramics, which might be due to the high concentration of $\mathrm{Ca}^{2+}$ favored the formation of HA whisker with perfect crystal structure during the hydrothermal process.

To balance the relationship between mechanical property and bioactivity of Ca-P bioceramic is a great challenge, the enhancement of mechanical property of Ca-P ceramics generally decreases their bioactivity. The present study certified that the construction of in-situ whiskers in BCP ceramics could realize the simultaneous enhancements of mechanical property and biological performance. After hydrothermal treatment, more bioactive sites might be exposed to facilitate the cell adhesion and spreading. Among them, $\mathrm{BCP}-\mathrm{Na}_{3} \mathrm{PO}_{4}$ with hollow whisker was more conducive to BMSCs spreading as comparing with the initial BCP ceramics (BCP-C), which might partly be due to its biphasic phases (Figure 5). Our previous work also observed that the proliferation and angiogenesis of HUVECs could be enhanced with a higher content of $\beta$ TCP phase. ${ }^{46}$ Moreover, the obtained BCP ceramics with in-situ whisker also processed the relatively higher ALP activity than the initial BCP ceramics (Figure 6). It is generally accepted that construction of specific topography on biomaterials is quite an effective route to regulate the protein adsorption and cellular behaviors, and further improve their biological performances. ${ }^{2,4,47,48}$ Previous studies have certified that the construction of specific micro-nano structure is an effective way to enhance the cellular activities and in-vivo biological performances of Ca-P bioceramics. In the study of Lin et $\mathrm{al}^{21,49,50}$ they demonstrated that HA bioceramics with hierarchical 3D micro-nanotextured surfaces stimulate osteoblast adhesion, growth and osteogenic differentiation. Chen et $\mathrm{al}^{51}$ introduced a kind of specific nanotopography constructed by the randomly oriented HA nanocrystal clusters could promote the adhesion of mesenchymal stem cells, which in turn promote osteogenic differentiation. Therefore, the insitu whisker growth has no negative but even positive effects on the biological performances of BCP ceramics.

Moreover, the ability of bone-like apatite formation is a direct criterion to evaluate the bioactivity of biomaterials in vitro. The bone-like apatite formation ability of BCP ceramic scaffolds with in-situ whisker growth was stronger than the initial BCP ceramics (BCP-C, Figure 7). Among them, the bone-like apatite formation ability of $\mathrm{BCP}-\mathrm{Na}_{3}$ $\mathrm{PO}_{4}$ seemed strongest, which surface was completely covered with bone-like apatite deposit. That might partly be because in-situ whisker growth on BCP ceramics might provide more nucleation sites to favor the re-deposition of bone-like apatite. Moreover, it could be predicted that the BCP ceramics with in-situ whisker growth possessed potential ability for osteogenesis in vivo. To sum up, the in-situ whisker growth in BCP ceramics is an effective route to achieve the simultaneous enhancements of mechanical strength and bioactivity.

\section{Conclusion}

As discussed, the present study introduced an effective approach to construct in-situ whisker on BCP ceramics. The phase compositions and morphologies of the in-situ whiskers on BCP ceramics could be adjusted by the hydrothermal conditions, especially the hydrothermal media. BCP-Na $\mathrm{NO}_{4}$ showed a unique hollow shape, and kept the original biphasic composition. The in-situ whisker growth had no adverse but even positive effects. Due to the growth of in-situ whiskers, the mechanical property and biological performance of the obtained $\mathrm{BCP}$ ceramics could increase simultaneously. Although further long-term evaluations are needed, we believe that the BCP ceramics with in-situ whisker growth can be a potential alternative to standard bone grafts for the treatment of bone defect repair.

\section{Acknowledgments}

This work was financially supported by the National Key Research and Development Program of China (2016YFC1102000, 2016YFC1102003), the National Natural Science Foundation of China (81671825, 52002256), 
China Postdoctoral Innovation Talent Support program (BX20180204), Postdoctoral Research \& Development Foundation of Sichuan University (0900904153024, 2019SCU12063), Scientific research and technical development Program of Yulin City (201934045). The authors thank Ms. Jiao Lu, Ms. Lingzhu Yu, and Mr. Guolong Meng for their help in SEM and CLSM measurements.

\section{Disclosure}

The authors report no conflicts of interest in this work.

\section{References}

1. Sunho O, Namsik O, Mark A, Ong JL. Bioceramics for tissue engineering applications - a review. Am J Biochem Biotechnol. 2006;2(2):49-56. doi:10.3844/ajbbsp.2006.49.56

2. Hong Y, Fan H, Li B, et al. Fabrication, biological effects, and medical applications of calcium phosphate nanoceramics. Mater Sci Eng. 2010;70(3-6):225-242.

3. Tang ZR, Tan YF, Ni YL, et al. Comparison of ectopic bone formation process induced by four calcium phosphate ceramics in mice. Mater Sci Eng C Mater Biol Appl. 2017;70:1000-1010. doi:10.1016/ j.msec.2016.06.097

4. Yuan HP, Fernandes H, Habibovic P, et al. Osteoinductive ceramics as a synthetic alternative to autologous bone grafting. Proc Natl Acad Sci US A. 2010;107(31):13614-13619. doi:10.1073/pnas.1003600107

5. Tang ZR, Li XF, Tan YF, Fan HS, Zhang XD. The material and biological characteristics of osteoinductive calcium phosphate ceramics. Regenerative Biomater. 2018;5(1):43-59. doi:10.1093/rb/ $\mathrm{rbx} 024$

6. Pina S, Oliveira JM, Reis RL. Natural-based nanocomposites for bone tissue engineering and regenerative medicine: a review. $A d v$ Mater. 2015;27(7):1143-1169.

7. Oh S, Brammer KS, Li YSJ, et al. Stem cell fate dictated solely by altered nanotube dimension. Proc Natl Acad Sci U S A. 2009;106 (7):2130-2135. doi:10.1073/pnas.0813200106

8. Kuo S-W, Lin H-I, Ho JH-C, et al. Regulation of the fate of human mesenchymal stem cells by mechanical and stereo-topographical cues provided by silicon nanowires. Biomaterials. 2012;33(20):50 13-5022. doi:10.1016/j.biomaterials.2012.03.080

9. Sjostrom T, Dalby MJ, Hart A, Tare R, Oreffo ROC, Su B. Fabrication of pillar-like titania nanostructures on titanium and their interactions with human skeletal stem cells. Acta Biomater. 2009;5 (5):1433-1441. doi:10.1016/j.actbio.2009.01.007

10. Dalby MJ, Gadegaard N, Tare R, et al. The control of human mesenchymal cell differentiation using nanoscale symmetry and disorder. Nat Mater. 2007;6(12):997-1003. doi:10.1038/nmat2013

11. McMurray RJ, Gadegaard N, Tsimbouri PM, et al. Nanoscale surfaces for the long-term maintenance of mesenchymal stem cell phenotype and multipotency. Nat Mater. 2011;10(8):637-644. doi: $10.1038 /$ nmat 3058

12. Vieu C, Carcenac F, Pepin A, et al. Electron beam lithography: resolution limits and applications. Appl Surf Sci. 2000;164:111-117. doi:10.1016/S0169-4332(00)00352-4

13. Wang P-Y, Li W-T, Yu J, Tsai W-B. Modulation of osteogenic, adipogenic and myogenic differentiation of mesenchymal stem cells by submicron grooved topography. J Mater Sci Mater Med. 2012;23 (12):3015-3028. doi:10.1007/s10856-012-4748-6

14. Kazemzadeh-Narbat M, Rouwkema J, Annabi N, et al. Engineering photocrosslinkable bicomponent hydrogel constructs for creating 3D vascularized bone. Adv Healthcare Mater. 2017;6(10):1601122. doi:10.1002/adhm.201601122
15. Myllymaa S, Kaivosoja E, Myllymaa K, et al. Adhesion, spreading and osteogenic differentiation of mesenchymal stem cells cultured on micropatterned amorphous diamond, titanium, tantalum and chromium coatings on silicon. J Mater Sci Mater Med. 2010;21 (1):329-341. doi:10.1007/s10856-009-3836-8

16. Popescu DC, van Leeuwen ENM, Rossi NAA, Holder SJ, Jansen JA, Sommerdijk N. Shaping amorphous calcium carbonate films into 2D model substrates for bone cell culture. Angewandte Chemie-Int Ed. 2006;45(11):1762-1767. doi:10.1002/anie.200502602

17. Wang X, Song W, Kawazoe N, Chen G. The osteogenic differentiation of mesenchymal stem cells by controlled cell-cell interaction on micropatterned surfaces. J Biomed Mater Res A. 2013;101 (12):3388-3395. doi:10.1002/jbm.a.34645

18. Carvalho A, Pelaez-Vargas A, Hansford DJ, Fernandes MH, Monteiro FJ. Effects of line and pillar array microengineered $\mathrm{SiO} 2$ thin films on the osteogenic differentiation of human bone marrow-derived mesenchymal stem cells. Langmuir. 2016;32 (4):1091-1100. doi:10.1021/acs.langmuir.5b03955

19. Krishna L, Dhamodaran K, Jayadev C, et al. Nanostructured scaffold as a determinant of stem cell fate. Stem Cell Res Ther. 2016;7:188. doi:10.1186/s13287-016-0440-y

20. Phillippi JA, Miller E, Weiss L, Huard J, Waggoner A, Campbell P. Microenvironments engineered by inkjet bioprinting spatially direct adult stem cells toward muscle- and bone-like subpopulations. Stem Cells. 2008;26(1):127-134. doi:10.1634/stemcells.2007-0520

21. Lin K, Xia L, Gan J, et al. Tailoring the nanostructured surfaces of hydroxyapatite bioceramics to promote protein adsorption, osteoblast growth, and osteogenic differentiation. ACS Appl Mater Interfaces. 2013;5(16):8008-8017. doi:10.1021/am402089w

22. Behnamghader A, Bagheri N, Raissi B, Moztarzadeh F. Phase development and sintering behaviour of biphasic HA-TCP calcium phosphate materials prepared from hydroxyapatite and bioactive glass. J Mater Sci Mater Med. 2008;19(1):197-201. doi:10.1007/s10856007-3120-8

23. Zhao HX, Jin H, Cai JY. Preparation and characterization of nano-hydroxyapatite/chitosan composite with enhanced compressive strength by urease-catalyzed method. Mater Lett. 2014;116:293-295. doi:10.1016/j.matlet.2013.05.082

24. Goncalves G, Cruz SMA, Ramalho A, Gracio J, Marques P. Graphene oxide versus functionalized carbon nanotubes as a reinforcing agent in a PMMA/HA bone cement. Nanoscale. 2012;4(9):2937-2945. doi:10.1039/c2nr30303e

25. Toru N. Study on diopside whiskers precipitation type hydroxyapatite. Mater Res Sot Symp Proc. 1990;175:71-76.

26. Mueller FA, Gbureck U, Kasuga T, Mizutani Y, Barralet JE, Lohbauer U. Whisker-reinforced calcium phosphate cements. J Am Ceram Soc. 2007;90(11):3694-3697. doi:10.1111/j.1551-2916.2007.01967.x

27. Suchanek W, Yashima M, Kakihana M, Yoshimura M. Processing and mechanical properties of hydroxyapatite reinforced with hydroxyapatite whiskers. Biomaterials. 1996;17(17):1715-1723. doi:10.10 16/0142-9612(96)87652-6

28. Suchanek W, Yashima M, Kakihana M, Yoshimura M. Hydroxyapatite/ hydroxyapatite-whisker composites without sintering additives: mechanical properties and microstructural evolution. J Am Ceram Soc. 1997;80(11):2805-2813. doi:10.1111/j.1151-2916.1997.tb03197.x

29. Ye X, Zhou C, Xiao Z, et al. Fabrication and characterization of porous 3D whisker-covered calcium phosphate scaffolds. Mater Lett. 2014;128:179-182. doi:10.1016/j.matlet.2014.04.142

30. Zhu Y, Zhang K, Zhao R, et al. Bone regeneration with micro/nano hybrid-structured biphasic calcium phosphate bioceramics at segmental bone defect and the induced immunoregulation of MSCs. Biomaterials. 2017;147:133-144. doi:10.1016/j.biomaterials.2017.09.018

31. Deng Y, Liu M, Chen X, et al. Enhanced osteoinductivity of porous biphasic calcium phosphate ceramic beads with high content of strontium-incorporated calcium-deficient hydroxyapatite. J Mater Chem B. 2018;6(41):6572-6584. doi:10.1039/C8TB01637B 
32. Li X, Wang M, Deng Y, Chen X, Xiao Y, Zhang X. Fabrication and Properties of Ca-P bioceramic spherical granules with interconnected porous structure. Acs Biomaterials Sci Eng. 2017;3(8):1557-1566. doi:10.1021/acsbiomaterials.7b00232

33. Kokubo T, Takadama H. How useful is SBF in predicting in vivo bone bioactivity? Biomaterials. 2006;27(15):2907-2915. doi:10.10 16/j.biomaterials.2006.01.017

34. Yuan B, Chen Y, Lin H, et al. Processing and properties of bioactive surface-porous PEKK. Acs Biomaterials Sci Eng. 2016;2(6):977-986. doi:10.1021/acsbiomaterials.6b00103

35. Destainville A, Champion E, Bernache-Assollant D, Laborde E. Synthesis, characterization and thermal behavior of apatitic tricalcium phosphate. Mater Chem Phys. 2003;80(1):269-277. doi:10.10 16/S0254-0584(02)00466-2

36. Raynaud S, Champion E, Bernache-Assollant D, Thomas P. Calcium phosphate apatites with variable $\mathrm{Ca} / \mathrm{P}$ atomic ratio I. Synthesis, characterisation and thermal stability of powders. Biomaterials. 2002;23 (4):1065-1072. doi:10.1016/S0142-9612(01)00218-6

37. Wang J, Liu D, Guo B, et al. Role of biphasic calcium phosphate ceramic-mediated secretion of signaling molecules by macrophages in migration and osteoblastic differentiation of MSCs. Acta Biomater. 2017;51:447-460. doi:10.1016/j.actbio.2017.01.059

38. Hong Y, Fan H, Li B, Guo B, Liu M, Zhang X. Fabrication, biological effects, and medical applications of calcium phosphate nanoceramics. Mater Sci Eng R-Rep. 2010;70(3-6):225-242.

39. Li X, Liu M, Chen F, et al. Design of hydroxyapatite bioceramics with micro-/nano-topographies to regulate the osteogenic activities of bone morphogenetic protein-2 and bone marrow stromal cells. Nanoscale. 2020;12(13):7284-7300. doi:10.1039/C9NR10561A

40. Li X, Song T, Chen X, et al. Osteoinductivity of porous biphasic calcium phosphate ceramic spheres with nanocrystalline and their efficacy in guiding bone regeneration. ACS Appl Mater Interfaces. 2019;11(4):3722-3736. doi:10.1021/acsami.8b18525

41. Park HC, Baek DJ, Park YM, Yoon SY, Stevens R. Thermal stability of hydroxyapatite whiskers derived from the hydrolysis of alpha-TCP. J Mater Sci. 2004;39(7):2531-2534. doi:10.1023/B: JMSC.0000020021.82216.6b
42. Stulajterova R, Medvecky L. Effect of calcium ions on transformation brushite to hydroxyapatite in aqueous solutions. Colloids Surf a Physicochem Eng Aspects. 2008;316(1-3):104-109.

43. TenHuisen KS, Brown PW. Formation of calcium-deficient hydroxyapatite from alpha-tricalcium phosphate. Biomaterials. 1998;19 (23):2209-2217. doi:10.1016/S0142-9612(98)00131-8

44. Giannakopoulos AE, Breder K. Synergism of toughening mechanisms in whisker-reinforced ceramic-matrix composites. J Am Ceram Soc. 1991;74(1):194-202. doi:10.1111/j.1151-2916.1991.tb07317.x

45. Li JX, Narita T, Ogawa J, Wadasako M. In situ synthesis of porous ceramics with a framework structure of aluminium borate whisker. J Mater Sci. 1998;33(10):2601-2605. doi:10.1023/A:1004309403901

46. Chen Y, Wang J, Zhu XD, et al. Enhanced effect of $\beta$-tricalcium phosphate phase on neovascularization of porous calcium phosphate ceramics: in vitro and in vivo evidence[J]. Acta Biomater. 2015;11:435-448. doi:10.1016/j.actbio.2014.09.028

47. Shuai C, Liu G, Yang Y, et al. A strawberry-like Ag-decorated barium titanate enhances piezoelectric and antibacterial activities of polymer scaffold[J]. Nano Energy. 2020;74:104825. doi:10.1016/j. nanoen.2020.104825

48. Wei Y, Hu Y, Li M. et al. Fabrication of Sr-functionalized micro/ nano-hierarchical structure ceramic coatings on $3 \mathrm{D}$ printing titanium[J]. Surf Eng;2020. 1-8. doi:10.1080/02670844.2020.1748 349

49. Xia L, Lin K, Jiang X, et al. Enhanced osteogenesis through nano-structured surface design of macroporous hydroxyapatite bioceramic scaffolds via activation of ERK and p38 MAPK signaling pathways. J Mater Chem B. 2013;1(40):5403-5416. doi:10.1039/c3tb $20945 \mathrm{~h}$

50. Xia LG, Lin KL, Jiang XQ, et al. Effect of nano-structured bioceramic surface on osteogenic differentiation of adipose derived stem cells. Biomaterials. 2014;35(30):8514-8527. doi:10.1016/j.biomaterials.20 14.06.028

51. Chen Y, Sun Z, Li Y, Hong Y. Rapid osteogenic differentiation of mesenchymal stem cells on hydroxyapatite nanocrystal clusters-oriented nanotopography. RSC Adv. 2014;4(101):58019-58026. doi:10.1039/ C4RA10027A
International Journal of Nanomedicine

\section{Publish your work in this journal}

The International Journal of Nanomedicine is an international, peerreviewed journal focusing on the application of nanotechnology in diagnostics, therapeutics, and drug delivery systems throughout the biomedical field. This journal is indexed on PubMed Central, MedLine, CAS, SciSearch ${ }^{\mathbb{R}}$, Current Contents ${ }^{\mathbb{B}} /$ Clinical Medicine,
Journal Citation Reports/Science Edition, EMBase, Scopus and the Elsevier Bibliographic databases. The manuscript management system is completely online and includes a very quick and fair peer-review system, which is all easy to use. Visit http://www.dovepress.com/ testimonials.php to read real quotes from published authors. 